$$
\text { "zsinko" — 2007/2/14 — 13:17 — page } 225 \text { - \#1 }
$$

\title{
Analysis of the affective factors of learning mathematics among teacher trainees
}

\author{
ERZSÉBET ZsinKó
}

Abstract. The Hungarian National Core Curricula gives primacy to the development of abilities and the practical application of knowledge. The task of the training programme is primarily to prepare teacher trainees for the teaching and educating profession. As teachers, they are going to plan, organize, help, guide, control and evaluate the learning of mathematics of individuals and groups of students from the age of 6 to 10 (12), and cultivate their mathematical skills, thinking and positive attitude towards any mathematical activities. In order to train educators who are able to meet the above requirements on high standard, it is necessary to update the teacher training programme based on the trainees' preliminary knowledge and motivation level.

The key to learn about the child's mind and achieve conscious development is the systematization of factual knowledge and methodological awareness. The modern, flexible approach to subject pedagogy, based on pedagogy, psychology and epistemology, qualifies trainees to educate learners who understand and like mathematics. Therefore, it is essential to develop the trainees' positive approach to mathematics and arouse their demand for continuous professional improvement. (Programme of the four-year primary school teacher training, 1995.)

In our research we are looking for ways of ascertaining the starting parameters which have influence on the planning of the studies of mathematics and subject pedagogy. In this article we introduce a questionnaire by the means of which we collected information on the trainees' attitude and its changing towards mathematics. With the help of the analysis of the answers we paint a picture of the ELTE TÓFK (Eötvös Loránd University, Faculty of Elementary and Nursery School Teacher's Training) third year students' attitude to the subject, and we compare it to the tendencies noticed in the mass education. The energy invested in learning is influenced by the assumption of the relevance and importance of the subjects. Therefore we considered it also our task to reveal. Besides the students' attitude toward mathematics and their assumption about their own competence we have collected data also on their performance in the subject. Summarising the research results we show the advantages of the questionnaire, and summarise the observations which would indicate need for methodological changes in the mathematics teacher training.

Copyright (C) 2006 by University of Debrecen 


$$
\text { "zsinko" — 2007/2/14 — 13:17 — page } 226 \text { — \#2 }
$$

Key words and phrases: teacher pre-service and in-service education, affective aspects, attitudes, self concept.

ZDM Subject Classification: C29, B59.

\section{The description of the survey}

Subjects of the survey

The subjects of the survey were 146 third-year students of the college. They have studied mathematics and its subject pedagogy for four semesters. Besides academic development, students have met the practical problems of teaching mathematics on school visits during the previous semester where they observed several lessons and had the opportunity to gain personal impression both on the beauty and the difficulty of managing the learning of mathematics. While preparing for the profession they also have to get prepared and be able to make their students endear to their subjects.

Focus of the survey and its explanation

After the publication of the international survey results or as an effect of a change in the curriculum - as probably it is the case in all educational institutes - the programmes determining the qualification profile of the college are submit to scrutiny. The continuous improvement of the curriculum is required and influenced by the students' preliminary knowledge, characteristics of thinking, abilities and attitude towards the subject.

Deeper cognition of these fields is promoted by the analysis of the students' academic results, the questionnaires, test sheets, interviews and the classroom observations. In our survey we scrutinised the trainees' attitude towards mathematics.

It is essential that teachers develop positive attitude towards their own subject because they and their behaviour and activities become a dominant experience for school children. These experiences influence, form and direct, and in some cases even fully determine the children's relation to the subject which can have effect also on their further studies and thus on their career.

The recent changes due to quick development require lifelong learning on all walks of life. Double responsibility is incumbent on pedagogues. On one hand they have to acquire the necessary abilities for self-development to be able to study and like mathematics and its methodology. They will have to meet the 


$$
\text { "zsinko" — 2007/2/14 — 13:17 — page } 227 \text { — \#3 }
$$

challenges of the future on high standard and be able to flexibly adjust to the expectations of the actual curriculum. On the other hand they also have to shape their pupils' abilities so that they are prepared to learn independently and experience achievement and contentment.

The secret behind teaching mathematics as a positive experience for pupils lies in the teachers' ability to reflect their attitude to mathematics and making pupils realise the beauty of the subject. The deeper teachers believe in their subject themselves, the more genuine picture they can convey to their pupils.

To survey the attitudes towards mathematics in our research, we designed an easily applicable questionnaire. Its completion takes little time so it can be applied together with the test-sheet or any other questionnaires. The detailed introduction and analysis of our test-sheet is not in the focus of the present article, hence we present its content only to an extent necessary to understand our reference in the analysis of the questionnaire (more details see [23]).

We compiled the questionnaire so that we can receive information on the attitude towards mathematics and the students' own judgement of their competence in the subject.

- The students' interest in and emotions towards mathematics strongly influence the everyday practice of teaching. Thus, the connection between cognitive and affective factors cannot be ignored. Affective conditions determine whether a student feels the need for learning or not. These factors are also formed by the school itself, thus, more attention has to be paid on them. Better results can be achieved by arousing curiosity and developing effective learning skills and habits rather than by forcing learning without motivation [8].

- When confronting with a problem, students have to compare their own competence with the complexity of the problem. The judgement of competence is influenced by self-concept and motivation to perform. Since the students' - often unfounded - notion of mathematics and of their knowledge influences their answers to questions in connection with affectivity, we also included such questions in the questionnaires. Questions about self-concept regard how students see themselves in connection with learning and knowing mathematics. 


$$
\text { "zsinko" — 2007/2/14 — 13:17 — page } 228 \text { — \#4 }
$$

\section{Tools and procedure of the survey}

The questionnaire contains 13 questions and it aims at obtaining information about the affective factors (see Appendix). Two questions $(11,12)$ provide data to help the planning of a research to be carried out later. In four cases the answers have to be indicated on a 10-degree scale, in two cases answers have to be given in writing, while the others are multiple choice questions.

With the questionnaire we wished to collect information on

- the attitude towards mathematics as a subject

- about the interest in mathematics $(2,7,6)$

- about the influence of college studies on the interest in mathematics (8)

- about the opinion on the importance of mathematics $(1,13)$

- own judgement of competence inquiring about

- persistence $(4,5)$

- evaluating own knowledge (10)

- learning habits $(9,14)$

- energy devoted to learning $(3,13)$

We compared the answers regarding self-concept and judgement of own competence to the number of maths problems students were able to solve in a test-sheet.

When designing the test-sheet we focused on several aspects. We aimed at choosing problems which make it possible to activate various classes of skills so that we can examine which skills are the most easily activated ones for our students.

When compiling the test-sheet, it was an important aspect to include several realistic problems (Problems 2, 3 and 4). We also considered the fact that meaningful learning can be detected best in problems where students are required to apply knowledge in both known and unknown situations. International surveys prove that Hungarian students perform well if questions are presented in a form they got accustomed to at school but are less successful when problems require the application of knowledge in realistic problems. This was the result of the PISA-survey in 2000 as well [18]. This indicates that learning at school does not necessarily help students cope with everyday situations. With our survey we wished to create a picture of the applicability level of our students' knowledge by including realistic problems.

We were also curious what the students' problem solving abilities were like on the fields of mathematics which have not been the focus of their college studies 


$$
\text { "zsinko" — 2007/2/14 — 13:17 — page } 229 \text { — \#5 }
$$

yet. It was possible to do so, because, as mentioned above, the chosen problems were originally compiled for primary school children.

In the following analysis the results of the test-sheet are compared to students' own judgement of competence.

Students were assigned 55 minutes to accomplish the test-sheet and the questionnaire.

Data processing and evaluation

For data processing we intended to use straightforward methods so that the survey can be carried out in relatively short time at any occasions and that its application requires no extensive statistical knowledge. It also makes the results comprehensible for wider audience. Therefore, we summarized the data using Microsoft Excel. Besides comparing various data it also allowed us to create diagrams to illustrate connections.

During the analysis we demonstrate to what extent our hypotheses were verified by the gathered data. We have obtained information on the students' attitude towards mathematics throughout their four-semester studies in mathematics and subject pedagogy. Although the observations on their behaviour, their utterances about mathematics and their teacherly conduct during the first practice teaching are not objective, they can still provide realistic picture about the relation between students and the subject. We intend to strengthen this picture with the help of the questionnaire which studies the affective factors.

\section{Aims and results}

\section{Affective factors}

\section{Reputation of mathematics as a school subject}

In the design of the questionnaire, which was meant to study the affective factors, we considered the system of criteria compiled by Bloom (1971) and applied to the teaching of mathematics by Wilson (1971). The Wittman system of criteria (1976) offers wider interpretation and more profound application. Taking all the above into consideration, we compiled a questionnaire which informs us about the degree of interest towards mathematics and discovers the students' opinion on the avail and importance of the subject. In order to discover the validity of the students' opinions, we compared their judgement about their competence to the results of the test-sheet mentioned above. 
What we were interested in

We contrasted the original attitude towards mathematics as a subject and the changes in the attitude with the data of earlier surveys. Namely, we used the findings of a survey in 1999, which were published in the journal Hungarian Pedagogy by Benő Csapó (2000). In this survey, the attitudes towards the subject were measured in a 5 -degree scale, where students could evaluate mathematics from 1 to 5, 5 meaning "I like it very much". Our 10-degree scale was developed based on this evaluation. Here, students could rank mathematics from 1 to 10 on the list of subjects. (The results were contrasted by using the following formula: $[11-$ (answer) $] / 2$. If not an integer, we rounded the figure.) The diagram presents the mean and the standard deviation of attitudes towards mathematics.

Table 1

\begin{tabular}{|l|c|c|c|c|c|}
\hline & Grade 5 & Grade 7 & Grade 9 & Grade 11 & $\begin{array}{c}\text { Teacher } \\
\text { trainees }\end{array}$ \\
\hline Mean & 3.71 & 3.26 & 3.05 & 2.88 & $\mathbf{3 . 1 0}$ \\
\hline $\begin{array}{l}\text { Standard } \\
\text { deviation }\end{array}$ & 0.99 & 0.97 & 1.00 & 1.05 & $\mathbf{1 . 1 6}$ \\
\hline
\end{tabular}

The changes in the attitude are illustrated by the diagram more graphically.

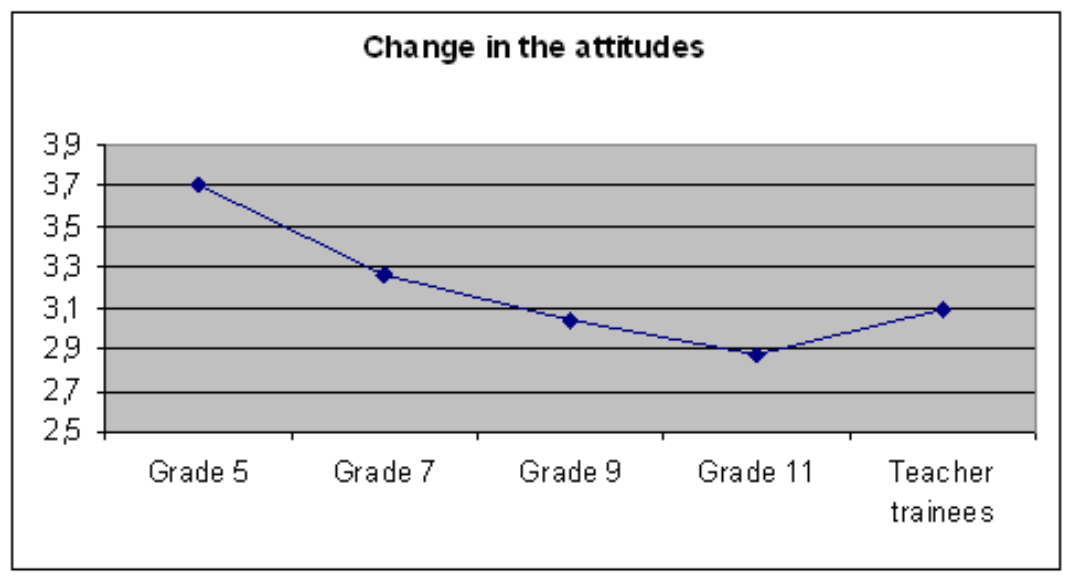

Figure 1
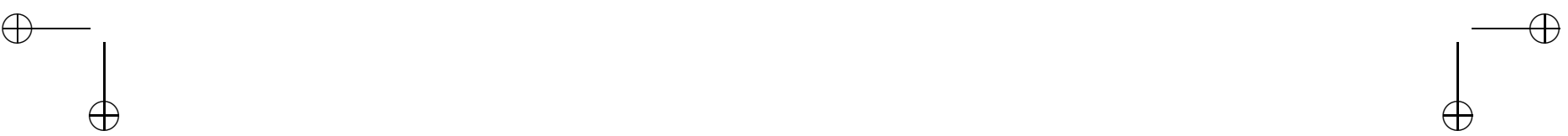


$$
\text { "zsinko" — 2007/2/14 — 13:17 — page } 231 \text { — \#7 }
$$

The diagram clearly shows the falling tendency in the attitudes towards mathematics in education. Third-year teacher trainees relate to mathematics as students in the beginning of the secondary school do. We would like to think that this improving tendency is due to their college studies.

In order to investigate the students' interest in mathematics we also wished to find out its position on the ranking list of subjects. We also wished to discover what kind of connection exists between its position and the opinions about its importance and if the solving of mathematical problems can possibly award students with pleasure. In accordance, we wished to group students as follows:

Group 1

- Students trying to avoid mathematics when choosing profession.

- Mathematics is ranked as one of the lasts $\left(8^{\text {th }}, 9^{\text {th }}\right.$, and $\left.10^{\text {th }}\right)$ on their list of subjects.

- Solving a mathematical problem has never given them pleasure yet.

Group 2

- Students not trying to avoid mathematics when choosing profession.

- Mathematics is one of their favourite subjects $\left(1^{\text {st }}, 2^{\text {nd }}, 3^{\text {rd }}\right)$.

- Solving a mathematical problem has already given them pleasure.

Group 3

All the students who cannot be reckoned among the previous two groups, i.e. who do not have any extreme opinion on mathematics, belong to Group 3.

What we have learnt

Only 2 students answered that solving a mathematical problem has never awarded them with pleasure yet, therefore we ignored this question in the further analysis. 22.6\% gave positive answers, and therefore, according to diagrams 1 and 2 we can state about the others that although the subject does not belong to their favourite ones, dealing with mathematics neither means a negative experience for them.

These findings correspond with the earlier academic results of the subjects of the survey. The mean of their marks being 3.76, mathematics cannot be their neglected subject. The data support our observations during the teaching practise. Trainees prepare for their first lesson with excitement and expectations and recount both on their success and difficulties. 
The trend of the students' grades in mathematics throughout their college studies gives an interesting picture.

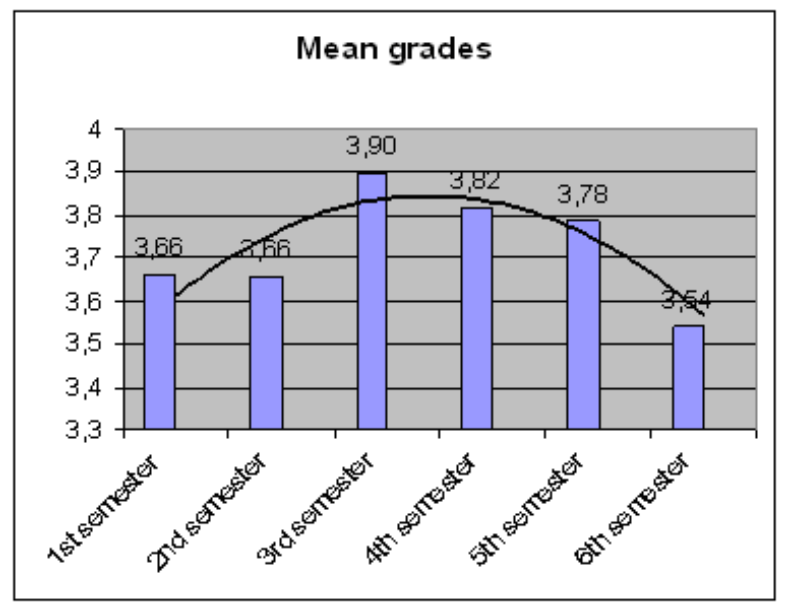

Figure 2

The higher mean in the third and fourth semesters can be explained by the fact that methodology obtains great role in the curriculum in this period.

At the same time, the decline in the sixth semester is unexpected and inexplicable. It is causeless even though in this semester the college syllabus contains combinatory, probability and statistics which were effaced by the earlier curriculum of secondary schools.

\section{What we were interested in}

We understand that students applying to teacher training colleges do not have mathematics in the centre of their range of interest. It is testified by the mean of their grades in mathematics in the last two secondary school years. Also, in our conversations they tend to express aversion rather than attraction to mathematics when arriving to college.

Therefore, college studies have the crucial task to change such initial approach, since the attitude towards the subject greatly affects learning. It is easier to progress with students who learn mathematics with pleasure, understand its avail and importance and are ready to make efforts for deeper comprehension. 


$$
\text { "zsinko" — 2007/2/14 — 13:17 — page } 233 \text { — \#9 }
$$

In the survey we wished to discover whether the aims of the pedagogical programme and its planned actions achieve the required effects.

According to the classification introduced earlier we examined, to what extent did college studies influence the development of students' interest in the subject.

In Group 1 (the Positive) and in Group 2 (the Indifferent) we examined the followings.

- Have college studies had any influence on the students' picture of the subject? (The first + sign denotes positive, the - sign negative change. $X$ denotes no change.)

- Have college studies had any influence on the students' opinion on mathematics? (The second + sign denotes positive, the - sign negative change. $X$ denotes no change.)

We summarised the answers to the above questions in Diagram 3. We expect that the picture and the opinion on mathematics as a subject correspond with each other, i.e. a change in one of them results in a change in the other, in the same direction. The expected relation is verified by calculating correlation.

\section{What we have learnt}

The statistical computations verified our preliminary concept, namely that the students' picture of mathematics (depth of knowledge about its content, avail and importance) influences the opinion on the subject. This is supported by the correlation between the answers to the questions 8a) and b) being 0.71 .

The diagram, representing the picture of mathematics and its judgement, seemingly does not reveal any significant difference between the Positive and the Indifferent group. The only noticeable tendency is that if there was any change in the picture or in the judgement of mathematics then it was mostly in the positive direction (Diagram 3). Whether the difference between the two groups was in fact unimportant, it was also verified by statistical methods. The $F$-test applied to the data affirms with probability 0.87 that there is no significant difference between the two groups.

\section{What we were interested in}

The energy invested in learning is strongly influenced by the assumption of the avail and relevance of knowledge. 


$$
\text { "zsinko" — 2007/2/14 — 13:17 — page } 234 \text { — \#10 }
$$

The opinion on the importance of mathematical competence was measured by two questions (1 and 13). They were also compared to the ranking of the subject (7).

- We examined how much the participants feel the interconnection between mathematics and reality, and to what extent they consider mathematical knowledge necessary in everyday life. It is compared to the summary of the opinions on the applicability of mathematical knowledge in future work.

- We were also concerned, to what extent students consider the knowledge gained at college to be applicable.

What we have learnt

- The series 2 and 3 of Diagram 4 are shifted to the right-hand side. It shows that students understand the importance of their mathematical studies together with the applicability of the acquired knowledge.

- The applicability of mathematics in real life is indicated by series 1 . The mean and the standard deviation of the answers on the 10-degree scale is 4.57 and 1.9 , respectively.

- We hoped that there will be only a few who rank mathematics after the $5^{\text {th }}$ position on the list of subjects while being aware of the importance of the knowledge acquired at college. According to Diagram 5, it is about the third of the students.

- Comparing the subject ranking and the necessity in future profession, Diagram 6 shows that the $47.94 \%$ of students likes mathematics and consider it to be important in their profession, at the same time. $32.19 \%$ of the students understands the necessity of mathematical knowledge, but does not like it. According to the data, almost $50 \%$ of the students belonging to this latter group (i.e. $16 \%$ of the total) do not even want to avoid having to deal with mathematics.

- Diagram 7 shows that $39 \%$ of the students like the subject but does not appreciate its necessity in everyday life. Therefore, we were curious how successful they were in solving the practical problems of the test-sheet (Problems 2, 3 and 4). In Diagram 8 we denoted by 1 the group of students who like mathematics and understand its applicability in everyday life. Group 2 includes students who like mathematics but do not understand its applicability, students in Group 3 do not like mathematics but understand its applicability and finally, group 4 represents students who do not like it nor understand its 


$$
\text { "zsinko" — 2007/2/14 — 13:17 — page 235 — \#11 }
$$

applicability in everyday life. According to the diagram, groups do not show significant difference in solving exercise 4. At the same time, in exercises 2 and 3 the results of students who do not like the subject proved to be weaker. These observations are also supported by data.

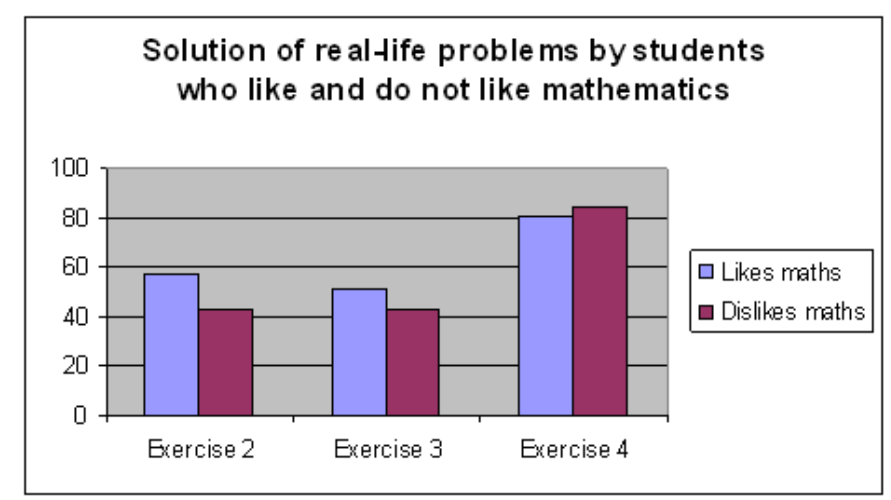

Figure 3

The Hungarian education of Mathematics has no "what's it good for" aspect. The applicability of the acquired knowledge occurs very rarely and if at all, it does so within the field of mathematics itself. Our survey results correspond to the findings of the PISA survey, 2000, namely that Hungarian students do poorly in solving real-life problems.

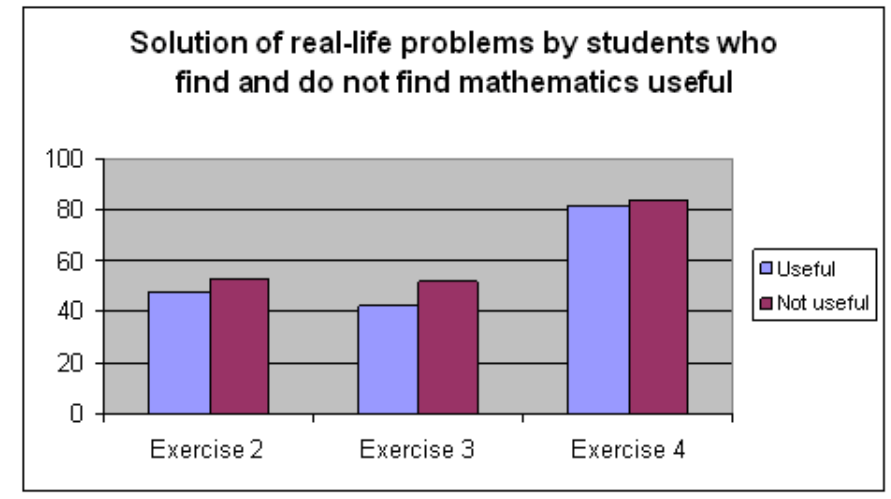

Figure 4
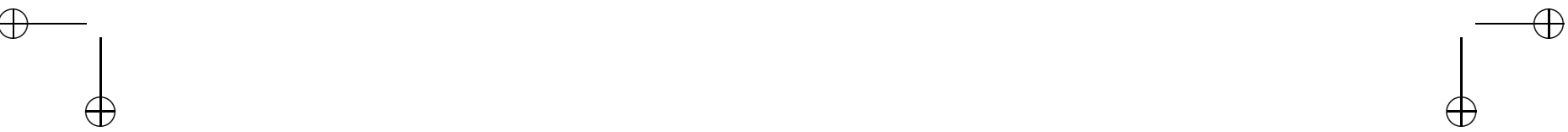


$$
\text { "zsinko" — 2007/2/14 — 13:17 — page } 236 \text { — \#12 }
$$

The diagram shows that students who claim to understand the applicability of mathematical knowledge in everyday life solve real-life problems less effectively than those who do not believe in the usefulness of their knowledge.

\section{Judgement of personal competence}

What we were interested in

Developing realistic view about ourselves is important, because suppositions about mathematics can affect performance when solving not routine-like problems [16]. Therefore we examined the students' judgement about the difficulty level of problems and compared to the results of the test-sheet.

a) The following 4 categories divide students according to their own judgement about perseverance.

Categories:

1. Likes challenges and is persistent when solving problems.

2. Likes challenges and but is not persistent when solving problems.

3. Dislikes challenges but is persistent when solving problems.

4. Dislikes challenges and is not persistent when solving problems.

What we have learnt

1. Suggests interested, open personality. $73.29 \%$

2. Suggests inconsistency. $6.85 \%$

3. Suggests strong will. $14.38 \%$

4. Suggests a person unable to judge difficulty level of problems realistically. $2.74 \%$

The data of Diagram 9 show that about the students' $90 \%$ consider themselves to be persistent and only $10 \%$ say that they dislike challenges.

b) In the scope of the 4 categories we examine the number of good solutions. A solution is regarded as good if the correct result appears regardless of the applied method, or if it is clear from the description of the solution steps that the train of thoughts leads to the correct result. In the case of problems with more ways of solution we accepted also only one or few solutions. On Diagram 10 we compared data characterizing the above categories to the total number of students.

The most significant differences between the above categories are the high proportion of students in category 2 having solved at least four problems 


$$
\text { "zsinko" — 2007/2/14 — 13:17 — page } 237 \text { — \#13 }
$$

correctly, and in category 1 having solved at least three problems correctly (Diagram 11).

Another analysis provides information about the persistence of students who solved 5, 4, 3, 2 or only 1 problem, respectively. It is conspicuous on Diagram 12 that among students who solved 5 problems the proportion of those who like challenges is high (more than 80\%). Furthermore, there is no student in this group who is not persistent and does not like challenges, either.

c) We compare the number of good solutions to the students' judgement of their own mathematical competence and vice versa. (Number of students belonging to one category is considered to be 100\%.)

Diagrams 13-16 show that the students' $65.8 \%$ evaluate their own knowledge satisfactory, $21.2 \%$ good and $13 \%$ poor. Only the third of all students is satisfied with this knowledge. Among students who solved all the 5 problems there are some who consider their own knowledge to be poor and, on the contrary, among students who gave only one correct solution, there are some who consider their own knowledge to be good. More than $40 \%$ of students' considering own knowledge to be good performed well, in fact. $70 \%$ of those who thought their knowledge satisfactory gave satisfactory or better performance. Half of the third group had indeed poor results.

d) According to the four categories introduced in paragraph a), we also examined the difference in learning habits. We expected greater independence from students belonging to the first category and dominant need for teacher guidance in category 4.

Only the students' $15.5 \%$ likes working alone, all the others need some kind of discussions which suggests, in most cases, uncertainty.

The proportions besides the categories are not surprising. Almost $20 \%$ of persistent students who like challenges, prefer working alone, while the most uncertain students require help (Diagram 17 and 18).

e) In connection with the learning habits it is also relevant to examine how much energy students devote to preparation for classes.

According to the data there is no significant difference between the divisions of the students. Unfortunately, the proportion of those who learn mathematics only before tests is rather high (35\%), and not more than $5.5 \%$ prepare continuously (Diagram 19).

f) In connection with the time devoted to learning at home we also examined the students' problem solving skills. Diagram 20 caused some surprise, because 


$$
\text { "zsinko" — 2007/2/14 — 13:17 — page 238 — \#14 }
$$

among students who prepare continuously there was none who could have solved all the problems correctly, although, all of them gave correct answer to at least two. Their general performance is slightly better than of those not preparing continuously. Based on statistical computations we can say with probability 0.82 that no significant difference exists between those who prepare rarely and those who only study prior to exams.

\section{Conclusions}

The survey described above can serve as a chain-loop in the process whose aim is to improve the curriculum of the teacher training institutes.

The analysis of the questionnaire and the test-sheet led to conclusions worth considering.

(1) We can not be satisfied with how students judge the applicability of mathematics in everyday life (Diagram 7). Comparing the results of the 5 test-sheet problems (Diagram 21), the poor results of Problems 2 and 3 are outstanding. Results of Problem 4 are somewhat better. These three problems contained realistic problem situations. Based on our survey, the claim to put more emphasis on pointing out the connection of reality and mathematics seems justified, also in the training process of teachers. It is necessary to strengthen this view among educators because only then can they themselves understand and make their students understand the importance of mathematics and its applicability in everyday life.

(2) The situation seems to be favourable when comparing the position of mathematics on the ranking list of subjects and the judgement of its necessity in work. Diagram 6 shows that the proportion of students, who like the subject and find it necessary in their work, is high. In all probability, they will make enthusiastic and well-prepared primary school teachers.

At the same time, there is need for decreasing the number of students who understand the necessity of mathematical knowledge, since very likely they wish to teach it in future, but do not like it. It is to be feared that they will be less successful in presenting the beauty of the subject to their students. It is our task to find methods to make mathematics a more favoured subject.

When choosing from the possible teaching methods, the ones which enhance the gradual development of students' activity and constructivity have to be preferred. Nor can it be ignored that more than $40 \%$ of the students favours working together with peers, thus we have to provide cooperative learning environment. According to Diagram 17 it is urgent to apply tools 
sustaining independent learning, thus the role, which interactive tools play in supporting learning, will have to gain ground [7, 12, 20].

The results of the survey are in agreement with my own experiences. This supports my conception that the applied questionnaire and test-sheet are suitable tools for mapping the starting parameters. This can serve as a basis for the differentiated planning of the content and the methodology of the teacher training curriculum, with attention to the students grounding and attitude.

Diagrams

\section{Reputrtion of mothemutics}

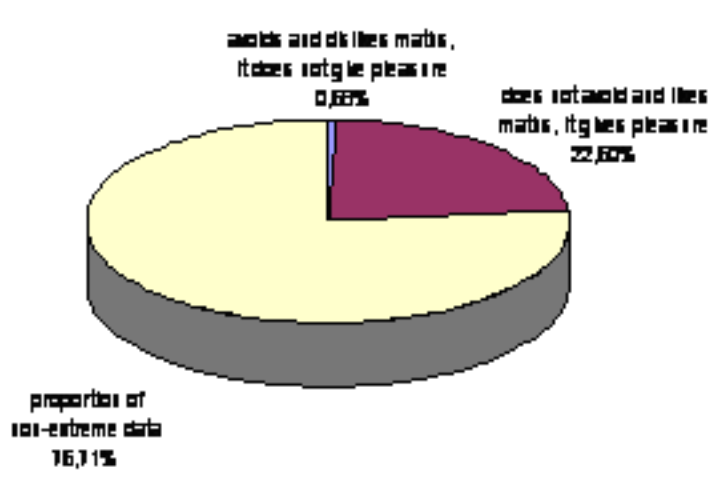

Diagram 1 
$\bigoplus$

$$
\text { "zsinko" - 2007/2/14 - 13:17 — page } 240-\# 16
$$

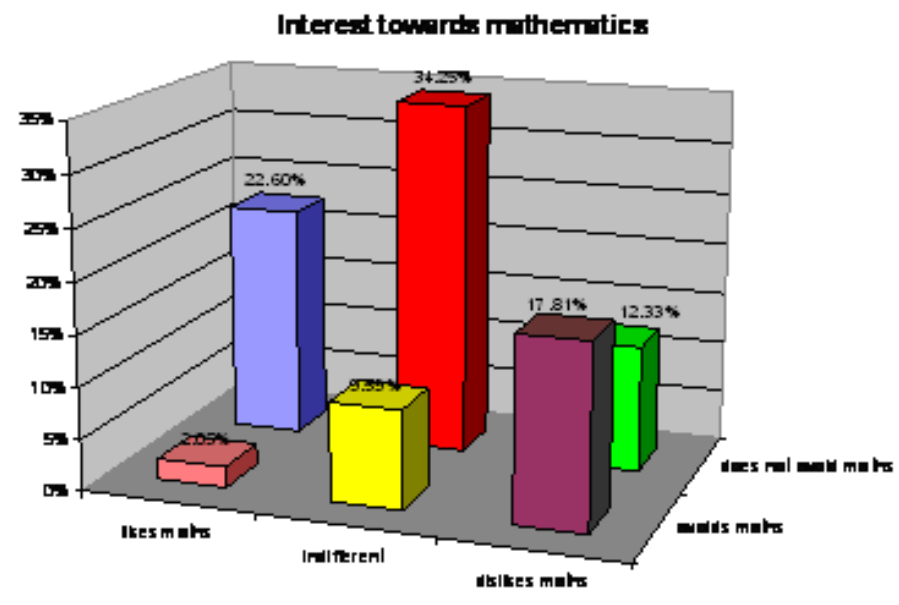

Diagram 2

\section{Change in the picture and opinion about methematics in $\mathbf{~}$}

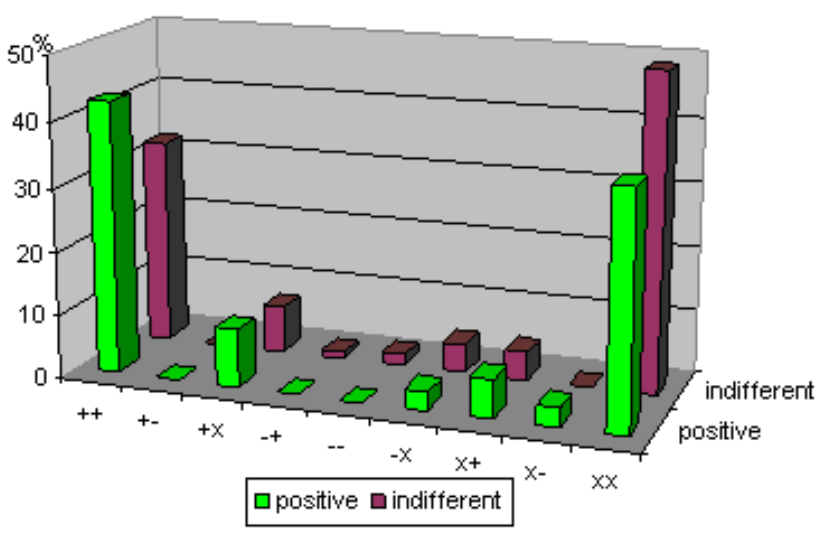

Diagram 3

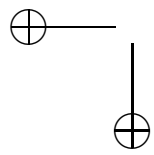


$\bigoplus$

$$
\text { "zsinko" — 2007/2/14 — 13:17 — page } 241 \text { — \#17 }
$$

\section{Opinion on the importance of mothemotical knowledge gained at college}

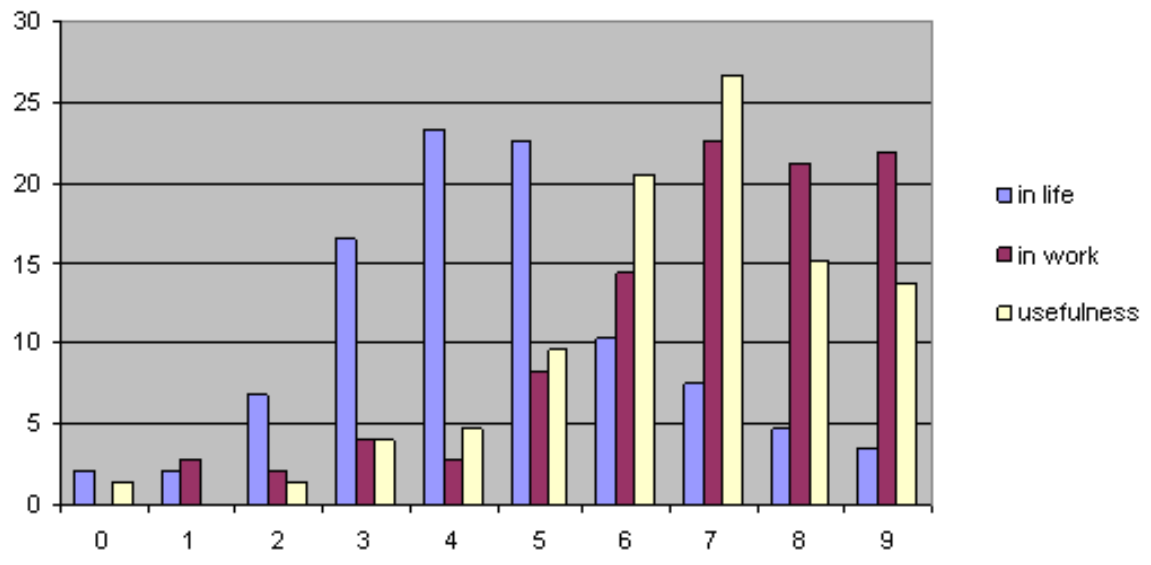

Diagram 4

\section{Connection between the ranking of mothematics and its usefulness}

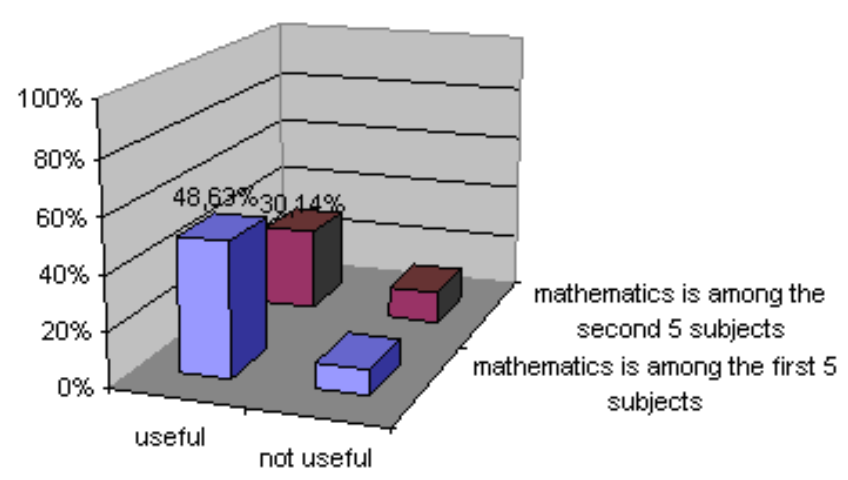

Diagram 5 


$$
\text { "zsinko" — 2007/2/14 — 13:17 — page } 242 \text { — \#18 }
$$

\section{Connection between the ranking of mathematics and its necessity in} work

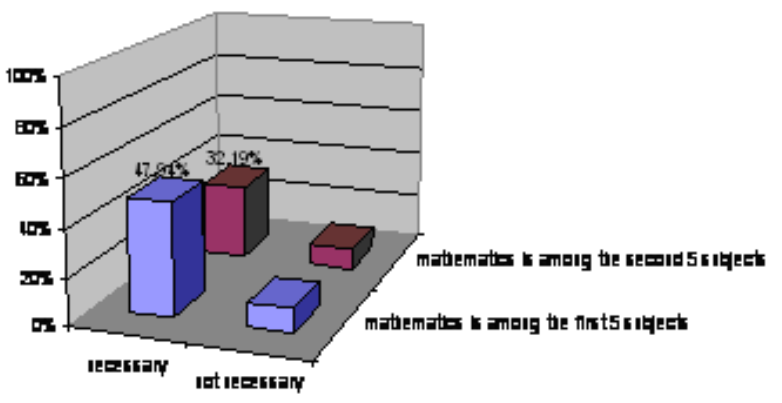

Diagram 6

\section{Connection between position of mathematics and its applicability in} everyday life

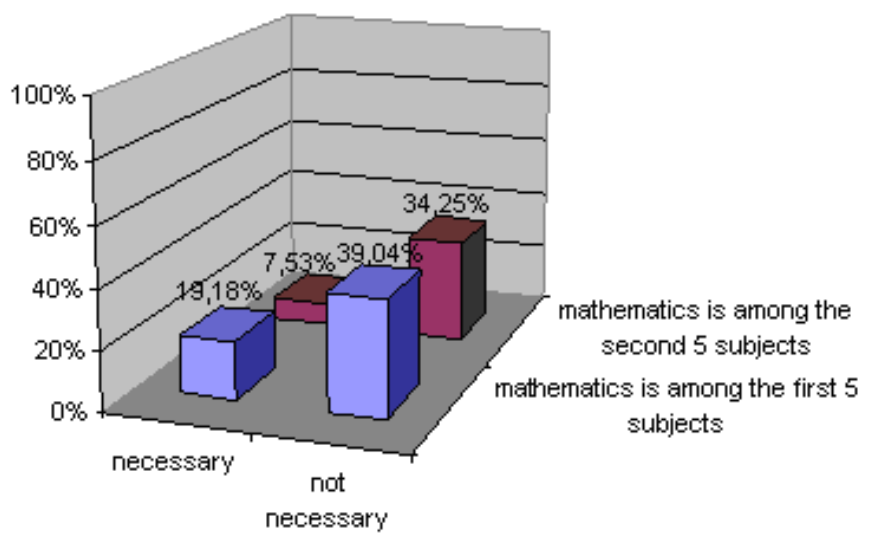

Diagram 7 
$\bigoplus$

$$
\text { "zsinko" — 2007/2/14 — 13:17 — page } 243 \text { — \#19 }
$$

Results of students belonging to each group with respect to problems 2, 3, and 4, in \%

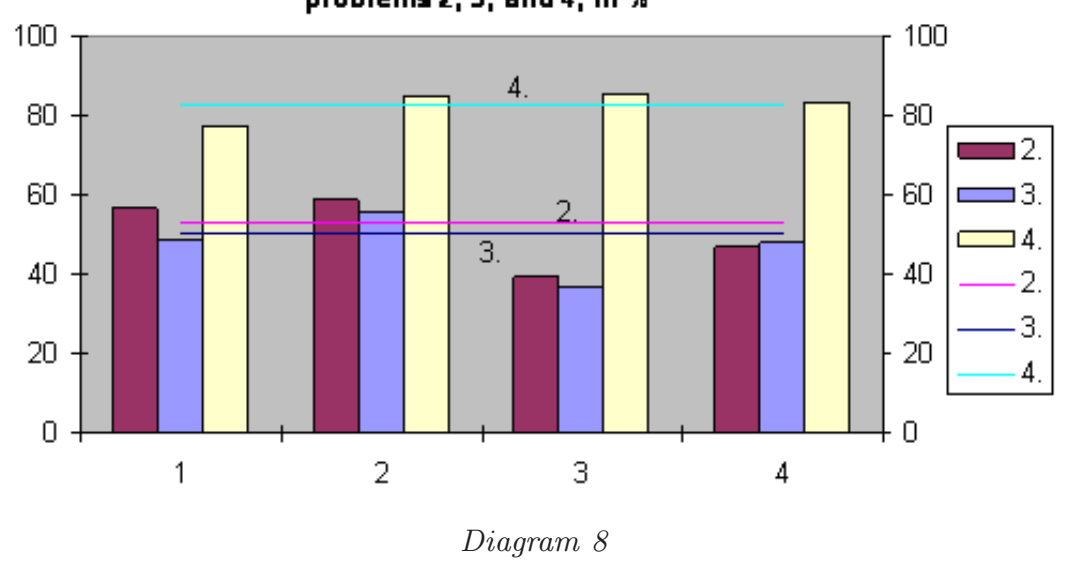

Pergeverance

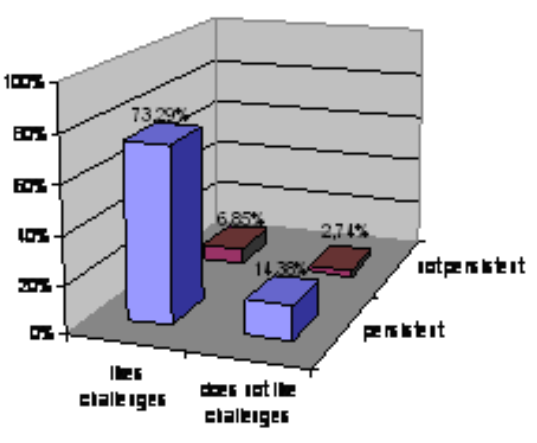

Diagram 9 
Proportion of students belonging to ench group who solved 5 , $4,3,2$ or 1 problems, in $X_{1}$ compared to total

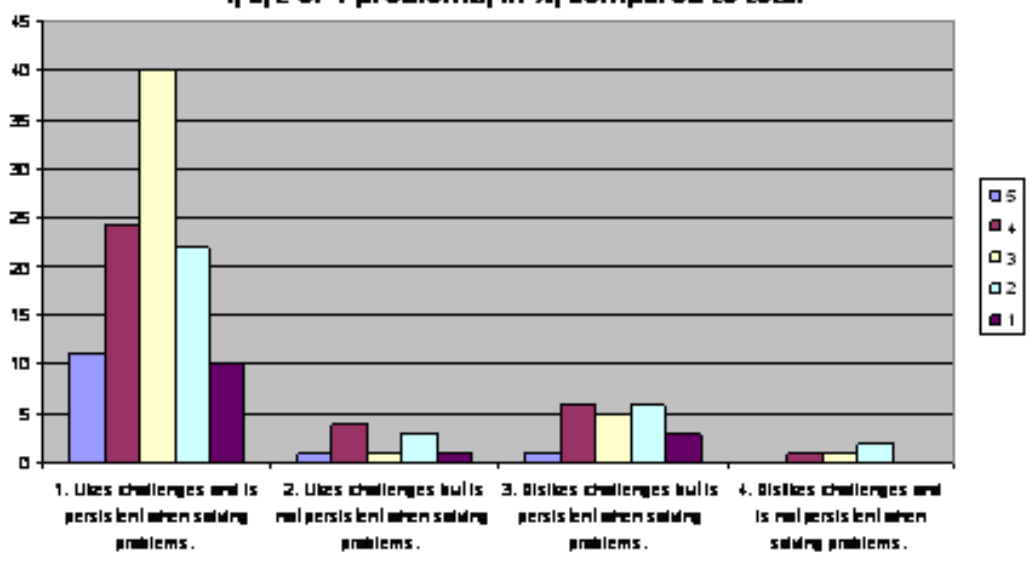

Diagram 10

Proportion of studens belonging to each group who solved 5 , $4,3,2$ or 1 problems, in $\mathbf{f}_{1}$ compared to the number of students in each group

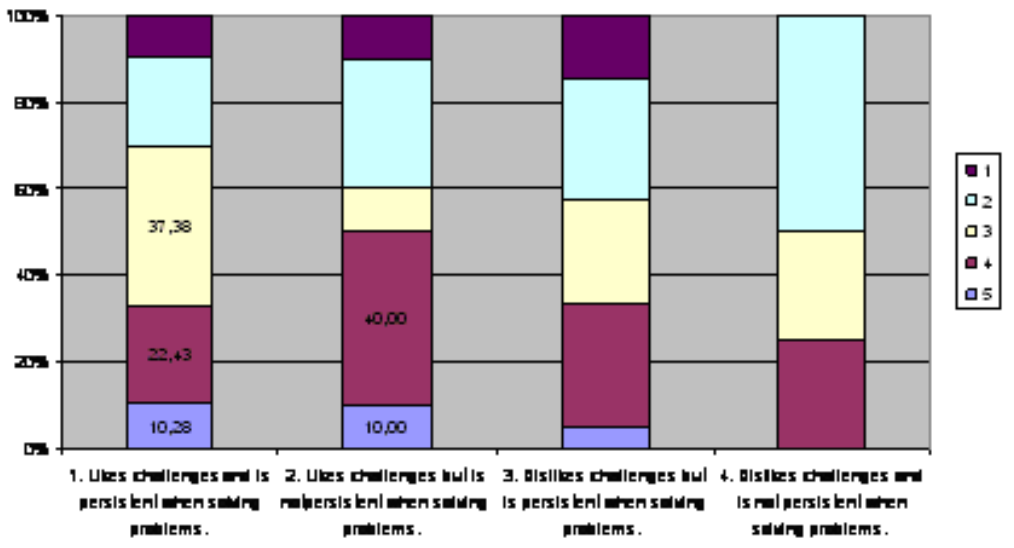

Diagram 11

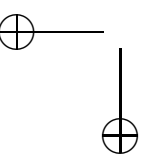




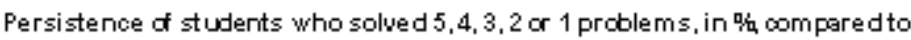
number of studerts in each group

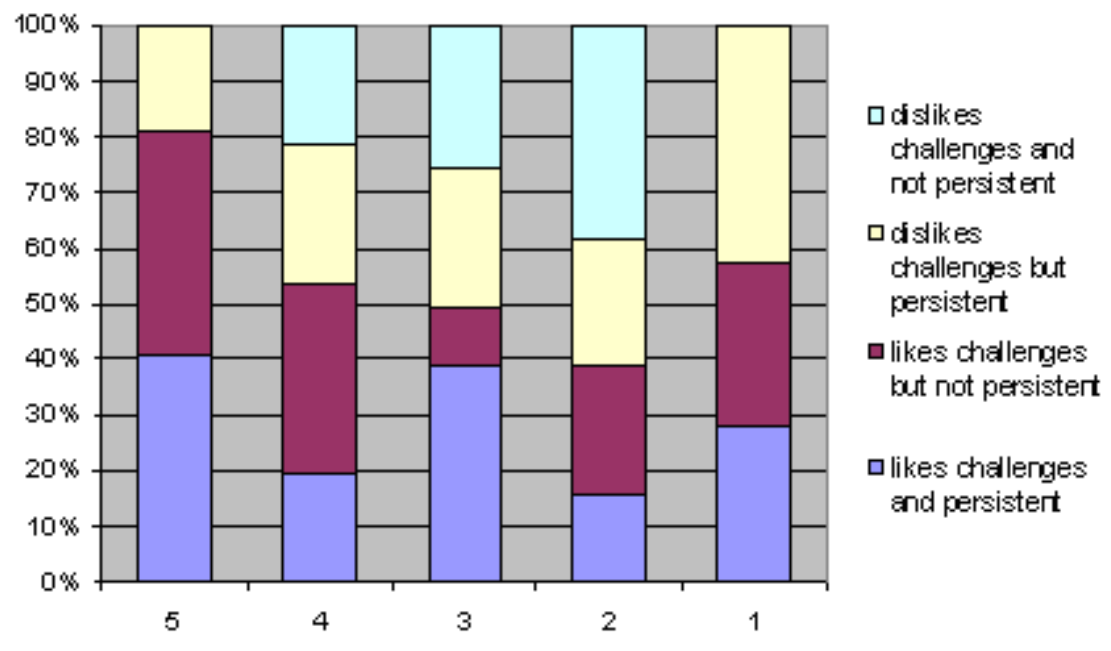

Diagram 12

\section{Eviluntion of own knowledge}

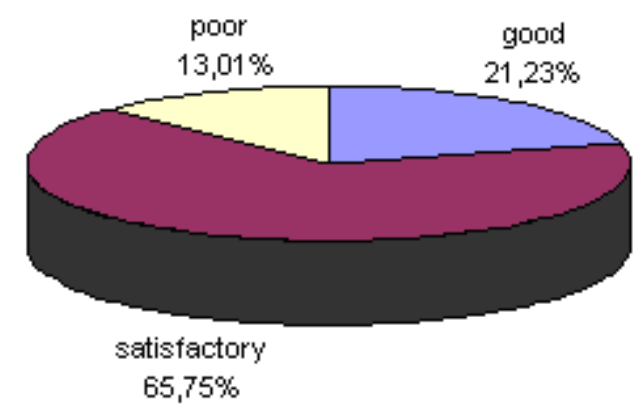

Diagram 13

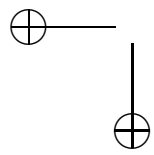




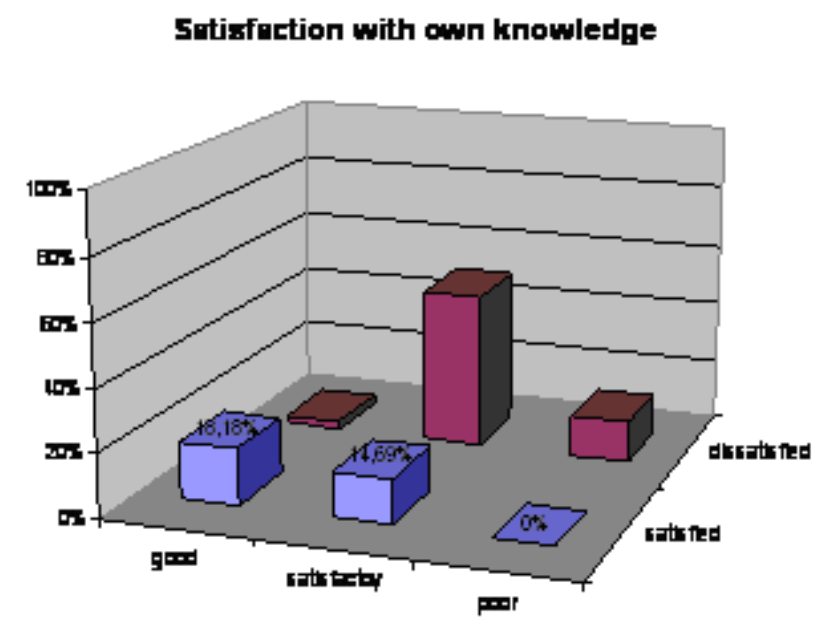

Diagram 14

\section{Comparizon of number of solutions and judgement of own} knowledge

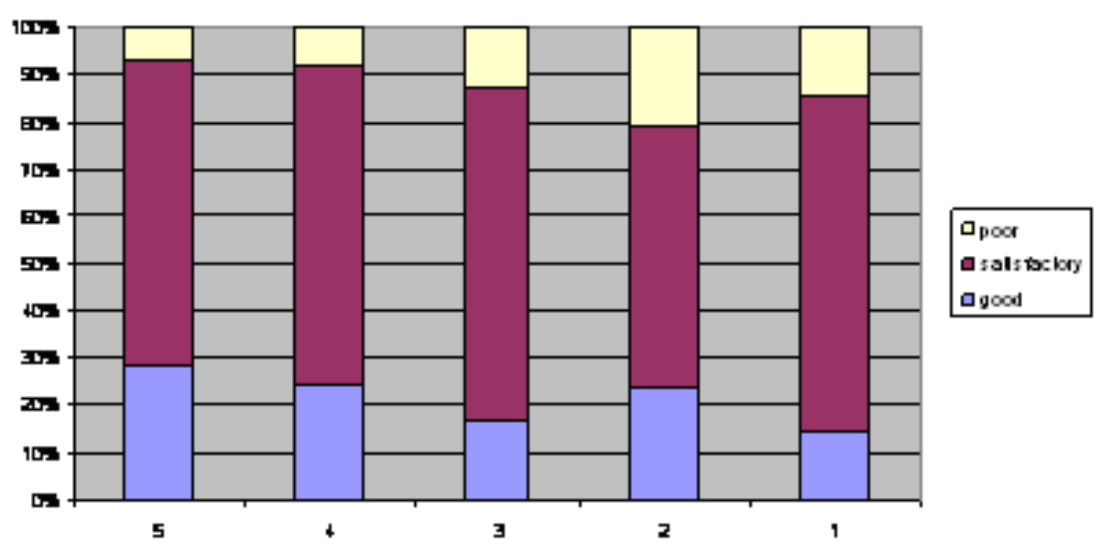

Diagram 15 
$\bigoplus$

$$
\text { "zsinko" — 2007/2/14 — 13:17 — page } 247 \text { — \#23 }
$$

Proportion of students who sohed 5, 4, 3, 2 or 1 problems, w.r.t judgement of own knowledge

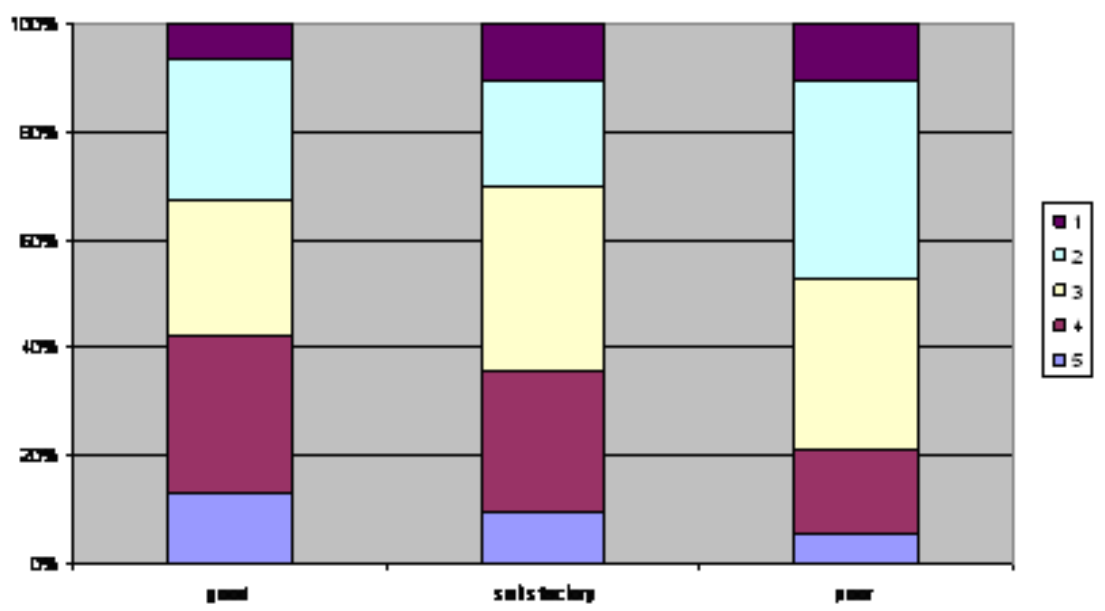

Diagram 16

\section{Learning habits}

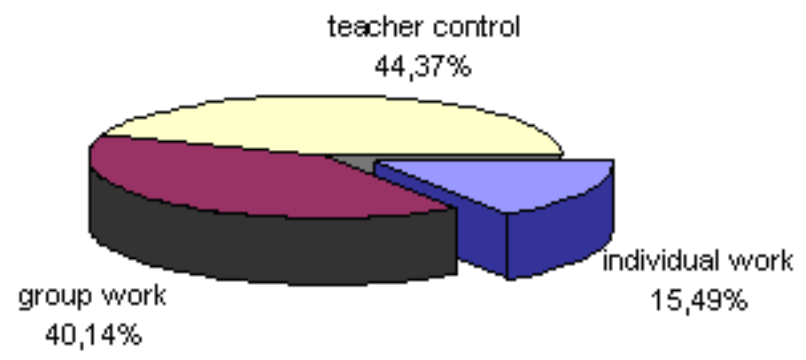

Diagram 17

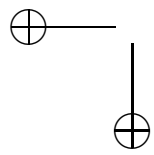


Independence wthin cathegories

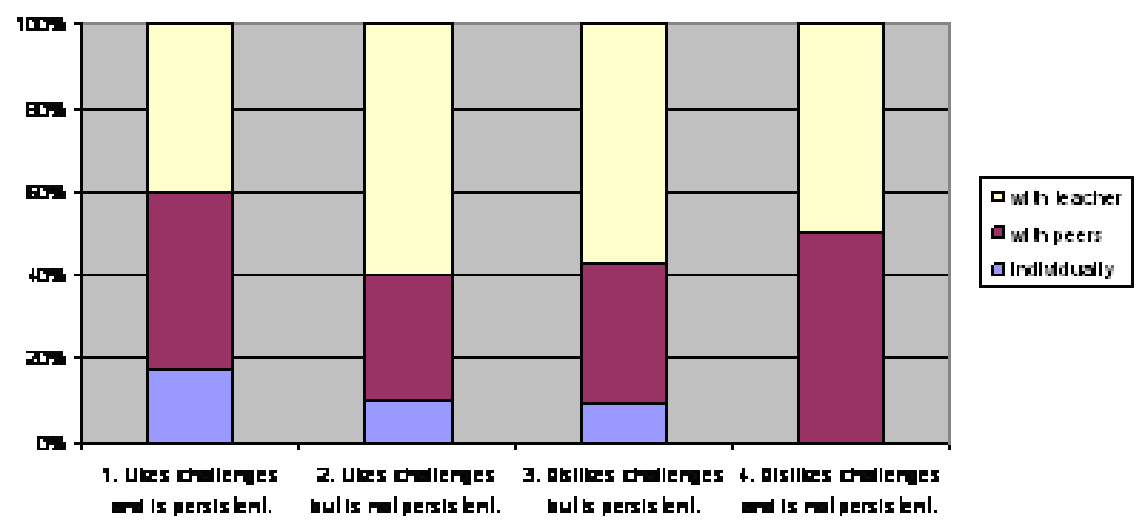

Diagram 18

Regularity of prepration, in $\mathbf{x}$

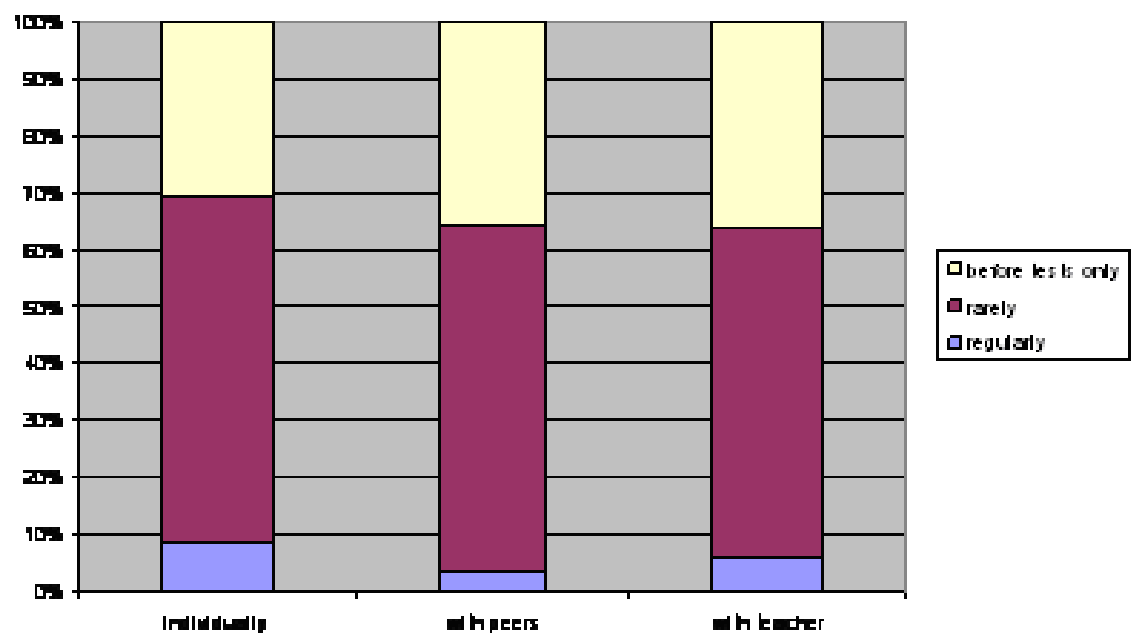

Diagram 19 


\section{Regularity of preparation and the number of sohed} problems, in $\mathbf{H}$

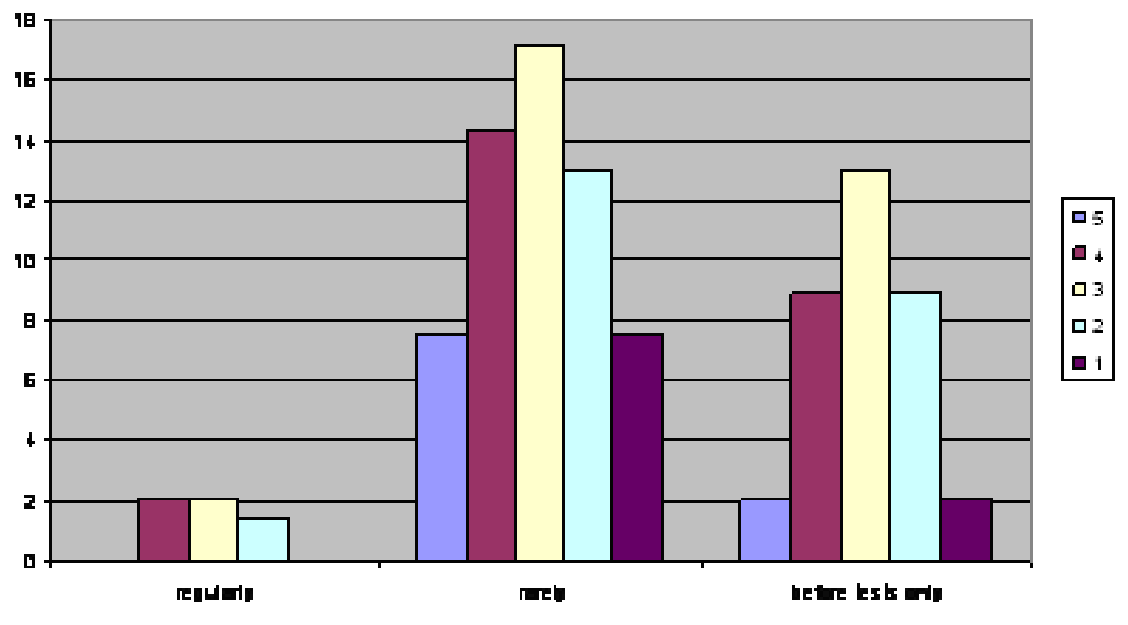

Diagram 20

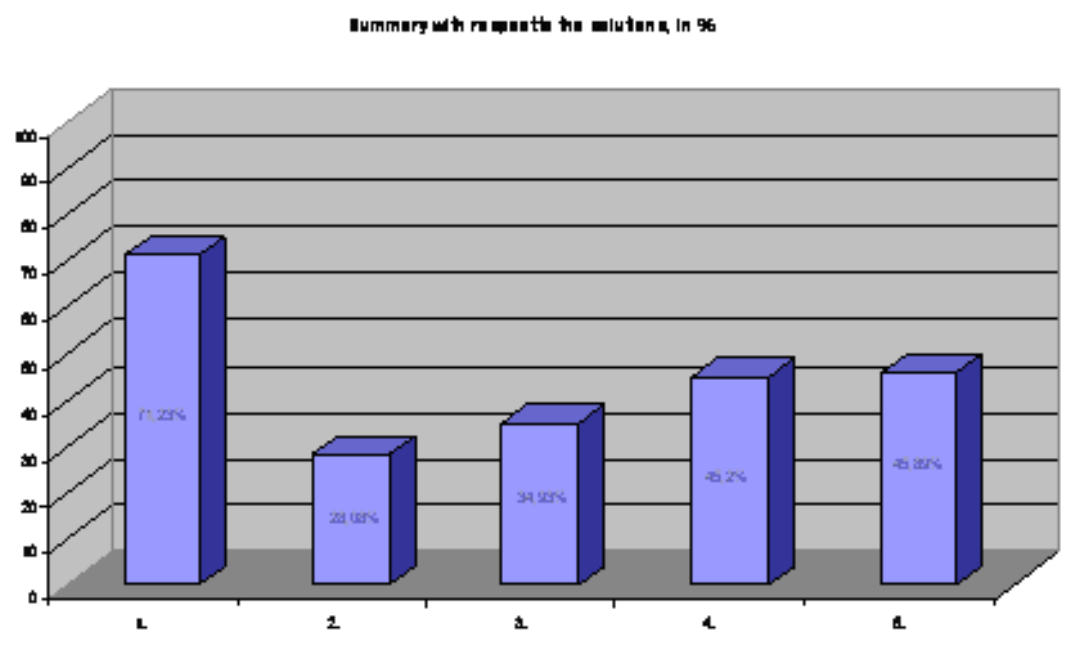

Diagram 21 


$$
\text { "zsinko" — 2007/2/14 — 13:17 — page } 250 \text { — \#26 }
$$

\section{Attachement \\ Questionnaire}

1. After graduation, to what extent do you think you will make use of the mathematical knowledge gained at college?

- in your future job?

$\begin{array}{llllllllll} & 1 & 1 & 1 & 1 & 1 & 1 & 1 & & \\ 0 & 1 & 2 & 3 & 4 & 5 & 6 & 7 & 8 & 9\end{array}$

- in your life?

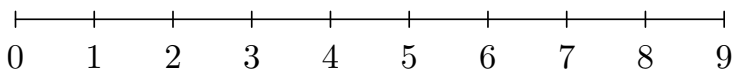

2. If you have the possibility to choose between jobs, do you make every effort to avoid mathematics?
a) yes
b) no

3. Do you prepare for mathematics sessions at home?
a) regularly
b) rarely
c) only before tests and exams

4. Do you like challenges?
a) yes
b) no

5. Are you persistent when solving problems?
a) yes
b) no

6. Has the solving of a mathematical problem ever given you pleasure yet?
a) yes
b) no

7. In the ranking list of subject, where would you put mathematics?

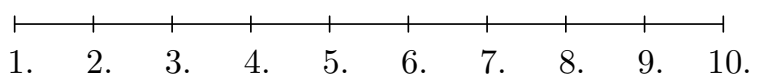

most favoured subject

least favoured subject 


$$
\text { "zsinko" — 2007/2/14 — 13:17 — page } 251 \text { — \#27 }
$$

8. How did college studies influence the followings:

- your picture of mathematics?
a) got better
b) got worse
c) did not change

- your affection towards mathematics?
a) got better
b) got worse
c) did not change

9. Which type of learning do you feel most suitable for yourself when learning mathematics?
a) individual work
b) group work
c) teacher control

10. On what level do you think your mathematics knowledge is?
a) good
b) poor
c) satisfactory

Are you content with this?
a) yes
b) no

11. Do you like working on the computer?

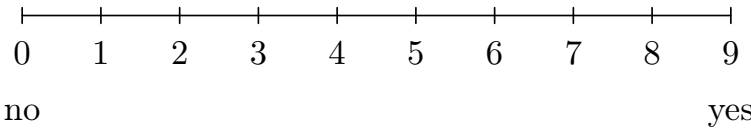

12. Do you think a computer software can enhance the learning of mathematics?

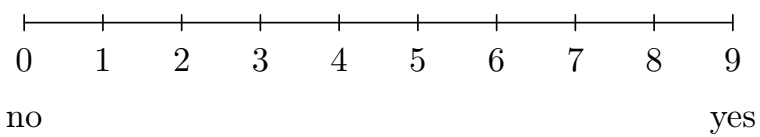

13. You learnt lots of mathematics at college. What do you think, why? 


$$
\text { "zsinko" — 2007/2/14 — 13:17 — page } 252 \text { — \#28 }
$$

14. How do you start solving a mathematical problem?

15. How difficult mathematical problems do you like to solve?

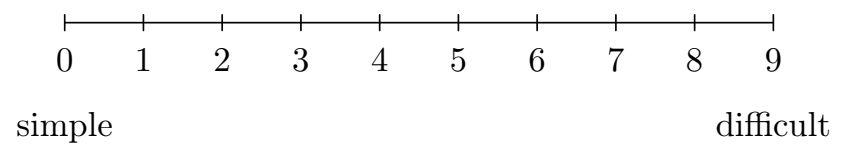

\section{References}

[1] Ambrus András, Didactics of Mathematics (in Hungarian: Bevezetés a matematikadidaktikába), ELTE Eötvös Kiadó, Budapest, 2004, 23-26.

[2] Báthory Zoltán, Our scientific education - changing explanations (in Hungarian: Természettudományos nevelésünk - változó magyarázatok), School culture (in Hungarian: Iskolakultúra) 10 (1999), 46-54.

[3] B. S. Bloom, J. T. Hastings, G. F. Madaus, Handbook of Formative and Summative Evaluation of Student Learning, New York, McGraw-Hill, 1971.

[4] B. S. Bloom, Taxonomie von Lernzielen im kognitiven Bereich, Ein System für die Klassifizierung von kognitiven Lernzielen, Beltz, Weinheim, 1972.

[5] Csapó Benő, Development of inductive reasoning: Cross-sectional measurements in an educational context, International Journal of Behavioral Development 20, no. 4 (1997), 609-626.

[6] Csapó Benő, Interconnections of attitudes towards school subjects (in Hungarian: A tantárgyakkal kapcsolatos attitüdök összefüggései), Hungarian Pedagogy (in Hungarian: Magyar Pedagógia) 100, no. 3 (2000), 343-366.

[7] Csapó Benő, The role of cognitive abilities in organising knowledge (in Hungarian: A kognitív képességek szerepe a tudás szervezésében), in: Pedagogical studies (in Hungarian: Tanulmányok a neveléstudomány köréből), (Báthory Zoltán, Falus Iván, eds.), Osiris Kiadó, Budapest, 2001, 270-293.

[8] Csapó Benő, Korom Erzsébet, Qualitative development of classroom learning and education (in Hungarian: Az iskolai tudás és az oktatás minőségi fejlesztése), in: Classroom learning (in Hungarian: Az iskolai tudás), (Csapó Benő, ed.), Osiris Kiadó, Budapest, 2002, 304-319.

[9] Csíkos Csaba, Dobi János, Mathematical Education (in Hungarian: Matematikai nevelés), in: Pedagogical studies (in Hungarian: Tanulmányok a neveléstudomány körébőll), (Báthory Zoltán, Falus Iván, eds.), Osiris Kiadó, Budapest, 2001, 355-372. 


$$
\text { "zsinko" — 2007/2/14 — 13:17 — page } 253 \text { — \#29 }
$$

[10] Dobi János, Affective conditions of learning mathematics (in Hungarian: A matematika tanulásának affektív feltételei), in: Pedagogy on the turn of the century (in Hungarian: Neveléstudomány az ezredfordulón), (Csapó Benő, Vidákovich Tibor, eds.), Nemzeti Tankönyvkiadó, Budapest, 2001, 268-279.

[11] Dobi János, Mathematical knowledge - learnt and understood (in Hungarian: Megtanult és megértett matematikatudás), in: Classroom learning (in Hungarian: Az iskolai tudás), (Csapó Benő, ed.), Osiris Kiadó, Budapest, 2002, 177-199.

[12] H.-J. Herber, Vásárhelyi É., Kompetenzstreben und Kompetenzerwerb, Salzburger Beiträge zur Erziehungswissenschaft 8, no. 2 (2004), 1-26.

[13] Nagy József, Education handbook for preparing pedagogical programmes including personality development (in Hungarian: Nevelési kézikönyv személyiségfejlesztö pedagógiai programok készítéséhez), Mozaik Oktatási Stúdió, Szeged, 1996.

[14] Nagy József, Improvement of cognitive skills and abilities (in Hungarian: A kognitív készségek és képességek fejlesztése), School culture (in Hungarian: Iskolakultúra) 1, 1999, 14-26.

[15] Réthy Endréné, Ananlysis of motivation to learn (in Hungarian: A tanulási motiváció elemzése), in: Pedagogy on the turn of the century (in Hungarian: Neveléstudomány az ezredfordulón), (Csapó Benő, Vidákovich Tibor, eds.), Nemzeti Tankönyvkiadó, Budapest, 2001, 153-161.

[16] A. H. Schoenfeld, Mathematical problem solving, Academic Press, Orlando, 1985.

[17] J. Torney-Purta, The monitoring of the affective outcomes, in: Monitoring the standards of education, (A. C. Tuijnman, T. N. Postlethwaite, eds.), Pergamon Press, Oxford, 1994, 151-169.

[18] Vári Péter (ed.), PISA 2000 Survey (PISA-vizsgálat 2000), Müszaki Könyvkiadó, Budapest, 2003.

[19] Vidákovich Tibor, Diagnostic survey on the level of knowledge and abilities (in Hungarian: Diagnosztikus tudásszint- és képességvizsgálatok), in: Pedagogy on the turn of the century (in Hungarian: Neveléstudomány az ezredfordulón), (Csapó Benő, Vidákovich Tibor, eds.), Nemzeti Tankönyvkiadó, Budapest, 2001, 314-327.

[20] Lev Szejonovics Vigotszkij, Thinking and talking (in Hungarian: Gondolkodás és beszéd), Trezor Kiadó, 2000.

[21] J. W. Wilson, Evaluation in secondary school mathematics, in: B. S. Bloom, J. T. Hastings, G. F. Madaus, Handbook of Formative and Summative Evaluation of Classroom Learning, New York, McGraw-Hill, 1971.

[22] Erich Wittmann, Grundfragen des Mathematikunterrichts, Vieweg Braunschweig, 1976, 33-36.

[23] Zsinkó E., An indirect survey to examine the learning conditions of mathematics among teacher trainees (Design and evaluation of a test sheet), in: K. J. Parisot, Vásárhelyi É., Positionen-Mathematikdidaktik in Entwicklung, Salzburg: Abakus, Salzburg, 2005, in print.

[24] Education in Hungary, 2003, National Institute of Public Education (OKI), Budapest, 2004. 


$$
\text { "zsinko" — 2007/2/14 — 13:17 — page } 254 \text { — \#30 }
$$

254 Zsinkó : Analysis of the affective factors of learning mathematics among teacher trainees

[25] National Core Curriculum, 2003, OM.

[26] Bollókné Panyik Ilona, Hunyady Györgyné (eds.), Programme of the four-year primary school teacher training (in Hungarian: A négyéves „tanító" szak programja), Tanító- és Óvóképző Főiskolák Főigazgatói Kollégiuma, Budapest, 1995.

ERZSÉBET ZSINKÓ

HUNGARY

E-mail: zsinkoe@kincsem.tofk.elte.hu

(Received March, 2005) 